\title{
Salvaging Native Plants from Sites Slated for Development: Stop Wasting Resources ${ }^{1}$
}

Kayla M. Hess, Taylor Clem, and Basil V. Iannone III

\section{Benefits of Native Plants for Urban Landscaping}

Interest in incorporating native plant species into landscaping has increased over the past few decades (Kauth and Perez 2011). One reason for this increase is greater public awareness regarding the potential benefits native species provide (Brzuszek et al. 2007). Native plants support local biodiversity by providing essential forage and shelter for wildlife and pollinators (Donaldson 2004; Ober and Knox 2013). In addition, once established, native vegetation adapted to dry and sandy soils can help conserve water due to their low water demand, thus decreasing the need for landscaping irrigation (US EPA 2002). Despite these benefits, only $25 \%$ of native plant species in Florida are commercially available in the state (Wilson et al. 2017). This low availability is because native plant species are typically sold in small markets and local native nurseries and have limited production (Norcini 2007). Despite these limitations, the number of native plant species being planted in residential landscaping and gardens has steadily increased over the past 30 years (Kauth and Perez 2011). In Florida, native plant sales have increased by $7.7 \%$ between 2005 and 2015 (Hodges and Haydu 2006; Hodges et al. 2016).

Organizations, such as Florida Native Plant Society (https:// www.fnps.org) and the Association of Florida Native Nurseries (https://www.fann.org/), provide information on native plant species, as well as their economic and environmental benefits. In addition, these programs provide information on how native plant species can be used in landscaping and how the proper selection and placement of the correct native plant species can promote water conservation and support wildlife.

\section{Limitations to Incorporating Native Landscape Plantings}

There are two major limitations to incorporating native plant species into urban landscaping. The first is plant availability. As stated above, native plant species are not as commercially available as nonnative species, and the diversity of available native plant species certainly lacks in comparison to what one finds in natural environments.

The second is that land development practices such as residential and commercial construction create environmental conditions that are strikingly different from those under which native plant species thrive, thereby hindering plant establishment and growth. During the construction phase, the landscape is altered as the site's elevation is typically raised by using multiple layers of soil fill, which is spread across the site. The soil fill is typically sterile and nutrient-poor sandy soils from different locations and/or dense and water-logged clay soils from onsite excavated stormwater ponds (Hochmuth et al. 2013). Once distributed across a site, fill is usually compressed due to heavy construction equipment (Hochmuth et al.

1. This document is FOR373, one of a series of the School of Forest Fisheries and Geomatic Sciences. Original publication date October 2021. Visit the EDIS website at https://edis.ifas.ufl.edu for the currently supported version of this publication.

2. Kayla M. Hess, MS student, School of Forest, Fisheries, and Geomatics Sciences; Taylor Clem, county Extension director and horticultural Extension agent UF/IFAS Extension Nassau County; and Basil V. Iannone III, assistant professor, residential landscape ecology, School of Forest, Fisheries, and Geomatics Sciences; UF/IFAS Extension, Gainesville FL 32611.

The Institute of Food and Agricultural Sciences (IFAS) is an Equal Opportunity Institution authorized to provide research, educational information and other services

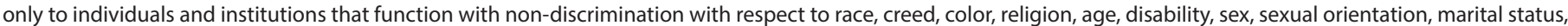

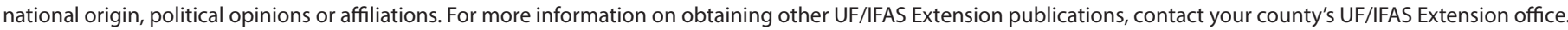
U.S. Department of Agriculture, UF/IFAS Extension Service, University of Florida, IFAS, Florida A \& M University Cooperative Extension Program, and Boards of County Commissioners Cooperating. Nick T. Place, dean for UF/IFAS Extension. 
2013; Shober et al. 2010). These sterile, nutrient-poor, and compressed soil conditions can prevent many native plant species from establishing and thriving due to the plants not receiving adequate nutrients and/or the root space to grow (Hochmuth et al. 2013). These conditions can even hinder the growth on nonnative species. The incorporation of soil amendments can improve growing conditions by providing essential nutrients, increasing soil water-holding capacity, and promoting healthy microbial communities (Bean and Dukes 2010; Trenholm et al. 1991). Regardless, proper selection of plant species (i.e., following the principle of "right plant, right place") and using those species that can withstand the environmental changes occurring during residential and commercial land development is important to ensure the successful establishment of, and subsequent benefits from, plants in urban landscapes.

\section{Salvaging Native Plants from Development Sites: Saving an Otherwise Wasted Resource}

To promote native plant species for urban landscaping, we need to find strategies to overcome the challenges presented by limited plant material and soil alterations. One such strategy is to salvage from sites slated for development native plant material that would otherwise be destroyed. Salvaging plant species from future development sites could contribute much-needed native plant material. These salvage efforts can prevent the waste of valuable plant material and reduce the resources required to grow new plant materials for these future development sites (e.g., water, fertilizers, pesticides) (Landowner Resource Center 2017). We also point out numerous plant species that can be incorporated successfully into compacted, nutrient-poor soils and other challenging growing conditions found within new urban developments (Bean and Dukes 2010).

This publication presents a case study that demonstrates the feasibility of salvaging plant material from future development sites to use in urban landscaping. This publication is intended for developers, Extension agents, planners, landscape architects, policymakers and landscapers who are interested in using, or promoting the use of, the native plant resources found on sites slated for development.

\section{Case Study}

To illustrate the potential to salvage and use native plant species from sites slated for development for urban landscaping, we compiled a list of plant species present on a proposed development site north of Gainesville, FL.
The proposed development site is managed for timber, has sandy soils with higher organic material closer to the soil surface (i.e., spodosol), and is dominated by pine trees (Pinus spp.) and bayberry shrubs (Myrica cerifera). The list of documented plant species was compiled by the authors of this publication and a consultant who assisted in the environmental assessment of the initial development plan. From this species list, we created a database listing each native species and their traits. The plant traits provided are broken up into three major categories: aesthetics, habitat, and function, where aesthetic traits describe what the plant looks like, habitat traits describe the plant's growing conditions, and functional traits describe how the plant effects the environment in which it grows. We used these attributes and general knowledge of current utility in urban landscapes to determine which species are well-suited for urban landscapes, and which of those are well-suited for the poor growing conditions typically found in new residential developments. This database can be downloaded from the Institutional Data Repository at the University of Florida from this link: https://ufdc.ufl.edu/IR00011318/00001.

\section{What We Found}

A total of 273 plant species, both nonnative and native, were documented in the proposed development site with 80 of these species being native species already found in urban landscapes (Table 1). The number of native landscaping plant species found illustrates the potential waste of plant materials if these species are not salvaged. In addition, we found these species varied considerably in their current landscaping usage, further illustrating the potential for salvaged plant materials to fit most landscaping functions. Examples of these species include red maple (Acer rubrum), dahoon holly (Ilex cassine), American holly (Ilex opaca), highbush blueberry (Vaccinium corymbosum), winged sumac (Rhus copallina), Leavenworth's tickseed (Coreopsis leavenworthii), Elliott's lovegrass (Eragrostis elliottii), and fine leaf blazing-star (Liatris tenuifolia) (Figure 1A-H). Red mapleserves as a shade tree that provides habitat to birds and pollinators (Gilman et al. 2018a). The dahoon and American holly are both a small tree/large shrub species that can provide privacy (Gilman et al. 2018b; Gilman et al. 2018c), while highbush blueberry is a lower-growing shrub species that can function as a shorter perimeter hedge (Florida Native Plant Society website 2020). Winged sumac is a small tree/large shrub that serves as an ornamental in places where large trees are not appropriate, such as along the roadsides and up against patios (Gilman and Watson 2014a). In contrast to species that provide boundaries and shade, Leavenworth's tickseed, Elliott's lovegrass, and fine leaf blazing-star are species that are best used as 
lower-growing ornamental species (Gilman et al. 2014; e.g., Florida Native Plant Society website 2020).

Not only did we find a suite of useful native landscaping species, 31 of these species are potentially well-suited for the harsh soil conditions found in newer residential developments (see Table 1). Examples of these species are longleaf pine (Pinus palustris), green ash (Fraxinus pennsylvanica), eastern red cedar (Juniperus virginiana), sand live oak (Quercus geminata), gopher apple (Licania michauxii), shiny blueberry (Vaccinium myrsinites), blueheart (Buchnera americana), and Texas vervain (Verbena halei) (Figure $2 \mathrm{~A}-\mathrm{H})$. We selected these species because they are able to grow in dry, sandy soils, which is an important trait, given that soils in new residential landscapes tend to be welldrained, sterile sandy fill. These species, like the prior listed examples, also provide a diversity of landscaping functions.
Longleaf pine and green ash are both tree species that serve as shade trees in urban landscaping (Gilman et al. 2018d, Gilman et al. 2018e), while eastern red cedar, a smaller tree, serves as a privacy screen along landscaping perimeters (Gilman and Watson 2014b). Sand live oak serves as an ornamental tree in urban landscaping and is highly used by birds and pollinators (Florida Native Plant Society website 2020). Gopher apple is a shrub that serves as a groundcover (Gilman 2014), while shiny blueberry, also a shrub, can serve as an ornamental plant within a garden or as a hedge (Florida Native Plant Society website 2020). Finally, both blueheart and Texas vervain are good examples of herbaceous ornamental plant species (Florida Native Plant Society website 2020).
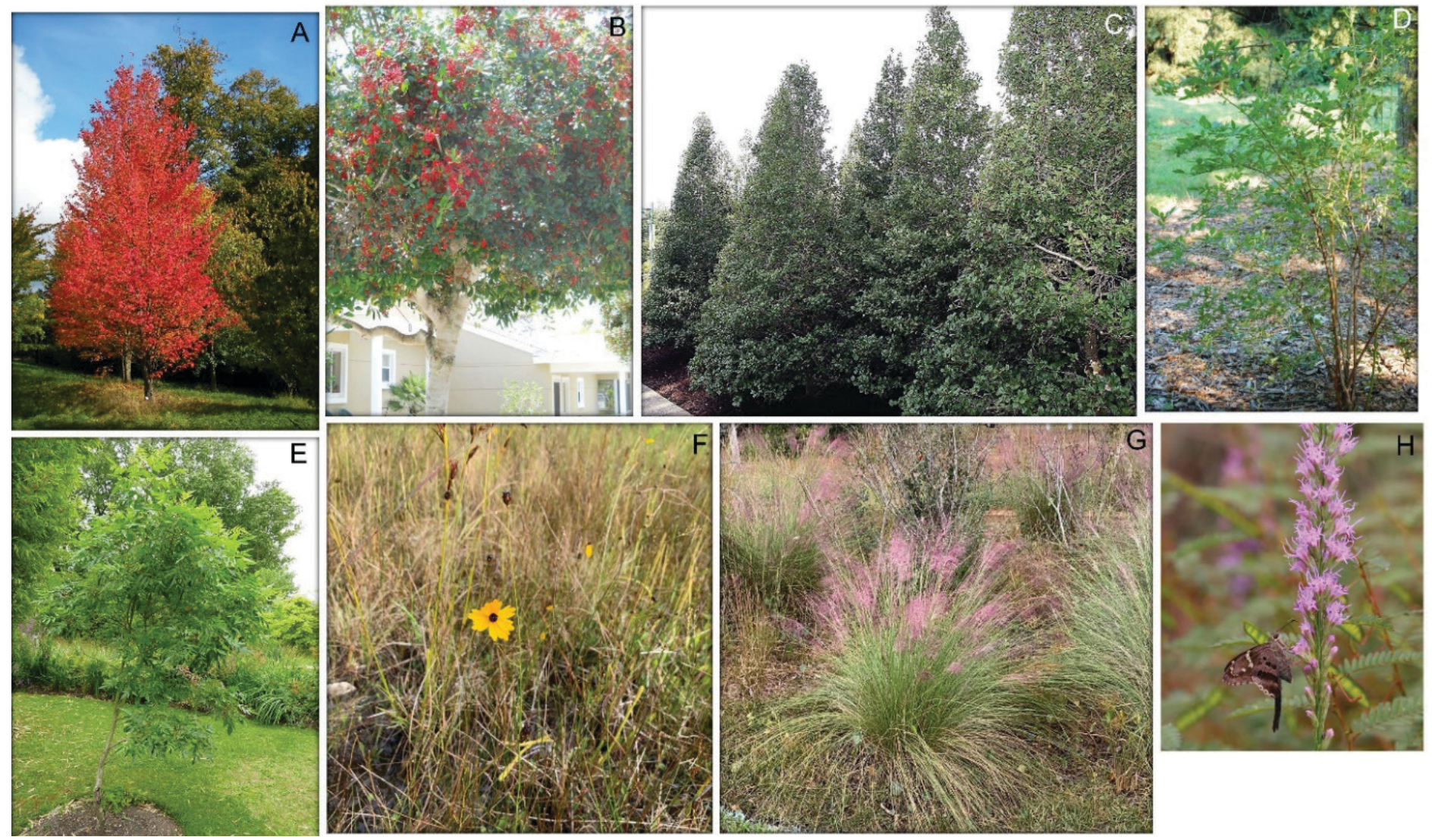

Figure 1. Examples of eight species common in urban landscapes that provide a diversity of landscaping functions, including (A) red maple, which provides shade, (B) dahoon and (C) American holly, which function as screens around landscaping perimeters, (D) highbush blueberry, which provides hedging, $(E)$ winged sumac, which contributes as an ornamental tree/shrub in places not well-suited for large trees, and (F) Leavenworth's tickseed, (G) Elliot's lovegrass, and (H) fine leaf blazing-star, which all serve as ornamental species in gardens.

Credits: A. Willow, CC BY-SA 3.0, via Wikimedia Commons; B. Stephen B Calvert Clariosophic, CC BY-SA 3.0, via Wikimedia Commons; C. Photo by David J. Stang, CC BY-SA 4.0, via Wikimedia Commons; D. Photo (c)2007 Derek Ramsey (Ram-Man), CC BY-SA 2.5, via Wikimedia Commons; E. Magnus Manske, CC BY-SA 3.0, via Wikimedia Commons; F. and G. Kayla Hess; H. Mary Keim, CC BY-NC-SA 2.0, via Flickr 

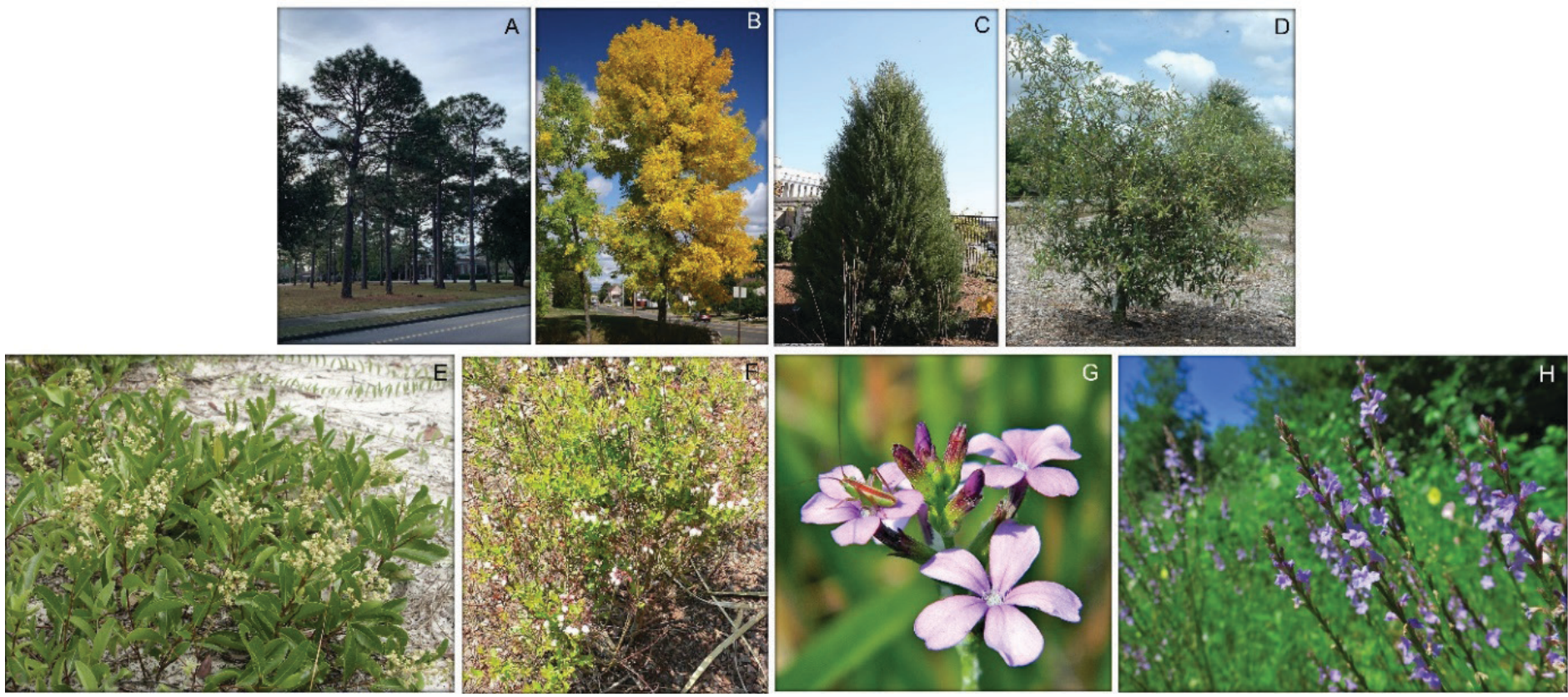

Figure 2. Examples of eight plant species native to Florida that are well-suited for the harsh growing conditions often found in new urban development sites, including (A) longleaf pine and (B) green ash, which both provide shade, (C) eastern red cedar, which functions as a screen around landscaping perimeters, (D) sand live oak, which serves as an ornamental species, (E) gopher apple, which functions as groundcover, (F) shiny blueberry, which is used as an ornamental in a garden or as hedging, and (G) blueheart and (H) Texas vervain, which both supply gardens as ornamental species.

Credits: A. Kayla Hess; B. Steven Katovich, USDA Forest Service, CC BY-CA 3.0 US, via Wikimedia Commons; C. Photo by David J. Stang, CC BY-SA 4.0, via Wikimedia Commons; D. Bruce Kirchoff from Greensboro, NC, USA, CC BY-CA 2.0, via Wikimedia Commons; E. Scott Zona, CC BY-NC 2.0, via Flickr; F. Raul654, CC BY-SA 3.0, via Wikimedia Commons; G. Bob Peterson from North Palm Beach, Florida, Planet Earth!, CC BY-SA 2.0, via Wikimedia Commons; H. Annika Lindqvist, CC BY-CA 4.0, via Wikimedia Commons

\section{Salvaging Strategies}

Using plant species from a site that is slated for development is not a new practice. The Native Plant Salvage Foundation and other organizations across the United States have been using native plants from development sites by harvesting and then transplanting them into restoration sites (Dorner 2002) and/or into landscapes of public facilities (Taft 2015). For instance, Pima County, AZ established a nursery for plants salvaged from development sites that are then re-planted in restoration sites or sold to the public (Taft 2015). There are three likely strategies for using plants found onsite at development projects. All three strategies described below can be employed separately or in combination, depending on developer needs and economic feasibility.

First, developers can harvest the material before clearing the land to incorporate into the development plan. Harvesting these species and using them in landscaping can cost less money and energy than growing new plants and transporting them from other locations (ADOT 2019). For instance, developers can harvest the plants from the proposed development site and either re-plant them into the landscapes of newly developed sites nearby (e.g., phased development) or use an on-site nursery to store the salvaged plants. The use of on-site nurseries is described below. Despite harvesting typically being able to offset costs of transportation from nearby nurseries, larger trees are an exception. The costs to harvesting, re-locating, and preventing loss of larger trees is higher than that for younger trees because of the stress on the more established root systems of older, larger trees (Garcia Chance et al. 2017).

There are likely situations where the abundance of suitable landscaping plants is too low to warrant the costs and effort required by developers to harvest them. Therefore, a second salvage option for these situations would be for the developer to allow others to harvest the materials to use elsewhere, e.g., in other commercial and/or residential developments, municipal lands, or nursery operations. Allowing others to harvest plants can offset the demolition cost to remove them. However, an exception to this rule is, again, the harvesting of larger trees. The costs of harvesting and re-locating larger trees and preventing their loss is higher than the cost for harvesting younger trees, again because of the stress that moving large trees causes to their more established root systems (Garcia Chance et al. 2017).

Third, if there is a limited amount of initial plant material but the species present are of great utility/value, or if the development is occurring over longer periods in multiple 
development phases, setting up an on-site nursery can be an effective plant salvaging strategy. This strategy, much like direct harvesting, can reduce project costs by limiting the need to grow and transport new plant material from elsewhere (Keeley 2000; Maiti 2013). However, as stated previously, the type of plant form matters for cost-efficiency. For example, older, larger trees requiring larger aboveground containers can cost more to harvest and maintain than younger trees requiring smaller containers (Garcia Chance 2017). In addition, the irrigation, fertilization, and staff required to set up and maintain an on-site nursery can make this strategy costly, but costs will vary depending on several factors, among them structural material, tools, and number of staff required (Ashby et al. 2016). Therefore, its encouraged to first estimate operating costs before choosing this strategy. Onsite nurseries are not only good for storing native plant species until the time of installation, but they also provide opportunity for propagation of new plants. These new plants can again offset costs of purchasing and transporting plants from elsewhere. Propagated plant material can also be incorporated into future development phases (Keeley 2000), making developing an onsite nursery a good option for developments occurring over longer periods of time. In addition, this strategy can generate revenue if there is a surplus of propagated plant material. Nevertheless, this third strategy will require developers to hire horticultural professionals capable of leading such an operation.

\section{Conclusion}

An increased awareness of native plant species and their benefits (e.g., supporting wildlife and water conservation) is leading an increased presence of native plant species in urban landscaping (Kauth and Perez 2011). However, limitations such as plant availability and soil alterations can hinder the wide adoption of landscaping with native plants. Salvaging native plants from sites slated for development can be one approach to overcoming these limitations within the context of expanding residential landscapes. From one such site, we found plenty of native species that could be salvaged, that are staples of urban and residential landscaping, and that can survive harsh post-development soil conditions.

The amount of plant material and number of species we found in this case study are important to reflect upon, given that the proposed development site was managed primarily for timber production and not conservation. Thus, it is likely that similar, or even greater, amounts of native plant resources are being wasted in other development sites, even those having histories of extractive uses such as ranching and forestry. We also provided examples of three different salvaging strategies that can be cost-effective and logistically feasible when applied strategically, including harvesting for on-site use, selling plant materials for others to use, and setting up an onsite nursery for long-term propagation. Of course, the economic feasibility of each strategy will need to be determined for each individual development project.

Given the projected development for Florida, salvaging plant material for landscaping use in proposed development sites can contribute to making development more sustainable. It will do so by contributing to the conservation of native plants, and through a reduction in resources needed for growing and transporting other species. It can also contribute to sustainability by helping to overcome plant supply barriers to the adoption of native landscaping. Salvaging native plants could also limit the need for irrigation and fertilizers and increase native biodiversity in urban and residential landscapes.

\section{Acknowledgments}

Support was provided by the UF/IFAS Center for Land Use Efficiency and the Program for Resource Efficient Communities. We gratefully acknowledge Audrey Genest, Tess Flemma, Francis Dinsmore, and Rashelle Deak for their efforts toward creating a database of native species traits. We are especially grateful for Weyerhaeuser for their comments and for providing access to their land.

\section{References}

Ashby, K., I. Farr, T. Laguna, M. Pham, J. C. Ruiz, and K. Shetty. 2016. "Assessing Capacity and Benefits of Native Plant Nurseries in the Los Angeles Region to Support Restoration of the Los Angeles River." Institute of the Environment and Sustainability.

Arizona Department of Transportation (ADOT). 2019. "Vegetation Management Guidelines - Native Plant Salvage." https://azdot.gov/sites/default/files/2019/09/ RVMG-Native-Soil-Stabilization.pdf.

Bean, E. Z., and M. D. Dukes. 2010. "Soil Amendments for Mitigation of Compacted Soils." Low Impact Development International Conference.

Brzuszek, R. F., R. L. Harkess, and S. J. Mulley. 2007. "Landscape Architect's Use of Native Plant in the Southeastern United States.” HortTechnology. 17 (1): 78-81. 
Donaldson, C. 2004. "Attracting Wildlife with Florida Native Plants." Florida Native Plant Society. https://www. fnps.org/resources/pubs.

Dorner, J. 2002. "An Introduction to Using Native Plants in Restoration Projects.” Plant Conservation Alliance.

Garcia Chance, L. M., M. A. Arnold, C. R. Hall, and S. T. Carver. 2017. "Economic Cost-Analysis of the IMPACT OF Container Size on Transplanted Tree Value." Horticulture. 3:29.

Gilman, E. F. 2014. “Licania michauxii Gopher Apple.” EDIS 2014. https://edis.ifas.ufl.edu/publication/FP342

Gilman, E. F., J. G. Norcini, and T. Howe. 2014. "Coreopsis leavenworthii: Leavenworth's Tickseed.” EDIS 2014. https:// edis.ifas.ufl.edu/publication/FP142

Gilman, E. F., and D. G. Watson. 2014a. "Rhus copallina: Shiny Sumac.” EDIS 2014. https://edis.ifas.ufl.edu/ publication/ST568

Gilman, E. F., and D. G. Watson. 2014b. "Juniperus virginiana: Eastern Redcedar.” EDIS 2014. https://edis.ifas.ufl. edu/publication/ST327

Gilman, E. F., D. G. Watson, R. W. Klein, A. K. Koeser, D. R. Hilbert, and D. C. McLean. 2018a. "Acer rubrum: Red Maple.” EDIS 2018. https://edis.ifas.ufl.edu/publication/ st041

Gilman, E. F., D. G. Watson, R. W. Klein, A. K. Koeser, D. R. Hilbert, and D. C. McLean. 2018b. "Ilex cassine: Dahoon Holly." EDIS 2018. https://edis.ifas.ufl.edu/publication/ ST299

Gilman, E. F., D. G. Watson, R. W. Klein, A. K. Koeser, D. R. Hilbert, and D. C. McLean. 2018c. "Ilex opaca: American Holly.” EDIS 2018. https://edis.ifas.ufl.edu/publication/ ST304

Gilman, E. F., D. G. Watson, R. W. Klein, A. K. Koeser, D. R. Hilbert, and D. C. McLean. 2018d. "Pinus palustris: Longleaf Pine.” EDIS 2018. https://edis.ifas.ufl.edu/publication/ ST469

Gilman, E. F., D. G. Watson, R. W. Klein, A. K. Koeser, D. R. Hilbert, and D. C. McLean. 2018e. "Fraxinus pennsylvanica: Green Ash.” EDIS 2018. https://edis.ifas.ufl.edu/publication/ ST266
Hochmuth, G., L. Trenholm, E. Momol, D. Rainey, C. Lewis, and B. Niemann. 2013. "The Role of Soil Management in Minimizing Water and Nutrient Losses from the Urban Landscape." EDIS 2016. https://edis.ifas.ufl.edu/ publication/SS593

Hodges, A. W., and J. J. Haydu. 2006. "Economic Impact of the Florida Environmental Horticulture Industry in 2005.” EDIS 2006. https://ufdcimages.uflib.ufl.edu/ IR/00/00/20/52/00001/FE67500.pdf

Hodges, A. W., H. Khachatryan, M. Rahamani, and C. D. Court. 2016. "Economic Contributions of the Environmental Horticulture Industry in Florida in 2015." UF/IFAS Sponsored Project Report to Florida Nursery, Growers and Landscape Association, Orlando, Florida. https://fred.ifas. ufl.edu/pdf/EconContEnvirHortIndFL2015-11-15-16.pdf.

Kauth, P. J., and H. E. Perez. 2011. "Industry Survey of the Native Wildflower Market in Florida." American Society for Horticultural Science. 21 (6): 779-788. https://journals.ashs. org/horttech/view/journals/horttech/21/6/article-p779.xml.

Keeley, M. B. 2000. “Developing Temporary On-Site Nurseries for the Purpose of Land Restoration." 2nd Interface Between Ecology and Land Development in California. pgs. 291-295.

Landowner Resource Center. 2017. "Successful Transplanting of Woodland Vegetation for Plant Salvage or Habitat Restoration Projects." Ontario Extension. https://www.grca. on.ca/wp-content/uploads/2017/07/trnsplntng.pdf.

Maiti, S. K. 2013. "Raising of Saplings for Forest Trees." Ecorestoration of the Coalmine Degraded Lands. Pg. 121-149.

Norcini, J. G. 2007. "Native Plants: An Overview." EDIS 2019. https://edis.ifas.ufl.edu/publication/EP297

Ober, H. K., and G. W. Knox. 2013. "Native Plants That Benefit Native Wildlife in the Florida Panhandle." EDIS 2019. https://edis.ifas.ufl.edu/publication/uw384

Shober, A. L., C. Wiese, G. S. Toor, and A. J. Reisinger. 2010. "Preplant Soil Assessment for New Residential Landscapes in Florida." EDIS 2019. https://edis.ifas.ufl.edu/publication/ ss534

Taft, B. 2015. "Improving Native Plant Salvage and Reestablishment." Pima County Community Development and Neighborhood Conservation. 
Trenholm, L. E., A. L. Shober, and E. Z. Bean. 1991. "Pre-

paring to Plant a Florida Lawn." EDIS 2018. https://edis.ifas. ufl.edu/publication/LH012

United States Environmental Protection Agency. 2002.

"Water-Efficient Landscaping: Preventing Pollution and

Using Resources Wisely.” EPA 832-F-02-002.

Wilson, S. B., J. A. Gersony, K. L. Nolan, J. C. Broda, and E. A. Skvarch. 2017. "Recommended Native Landscape Plants for Florida's Treasure Coast.” EDIS 2017. https://edis.ifas.ufl. edu/publication/EP348 
Table 1. Plant species documented in a proposed development site north of Gainesville, FL suited for, or used in, residential landscaping. Shown are scientific species names, common names, growth form (i.e., tree, shrub, herbaceous flower, grass, graminoid [grass-like plant], or fern), and whether the species is well-suited for soil conditions found in new developments (specified as a "Y").

\begin{tabular}{|c|c|c|c|}
\hline Common name & Scientific name & Growth form & $\begin{array}{c}\text { Potential suitability for new } \\
\text { development }\end{array}$ \\
\hline Red maple & Acer rubrum & Tree & $\mathrm{Y}$ \\
\hline Eastern redbud & Cercis canadensis & Tree & Y \\
\hline Common persimmon & Diospyros virginiana & Tree & Y \\
\hline Green ash & Fraxinus pennsylvatica & Tree & $\mathrm{Y}$ \\
\hline American holly & Ilex opaca & Tree & Y \\
\hline Yaupon & Ilex vomitoria & Tree & Y \\
\hline Red cedar & Juniperus virginiana & Tree & $Y$ \\
\hline Slash pine & Pinus elliottii & Tree & Y \\
\hline Sand live oak & Quercus geminata & Tree & $\mathrm{Y}$ \\
\hline Live oak & Quercus myrtifolia & Tree & $\mathrm{Y}$ \\
\hline Pond cypress & Taxodium ascendens & Tree & Y \\
\hline Bald cypress & Taxodium distichum & Tree & Y \\
\hline American elm & Ulmus Americana & Tree & Y \\
\hline Sparkleberry & Vaccinium arboretum & Tree & Y \\
\hline American hornbeam & Carpinus caroliniana & Tree & -- \\
\hline Common buttonbush & Cephalanthus occidentalis & Tree & -- \\
\hline Swamp dogwood & Cornus foemina & Tree & -- \\
\hline Loblolly bay & Gordonia lasianthes & Tree & -- \\
\hline Dahoon holly & Ilex cassine & Tree & -- \\
\hline Sweetgum & Liquidamber styraciflua & Tree & -- \\
\hline Southern magnolia & Magnolia grandiflora & Tree & -- \\
\hline Sweetbay & Magnolia virginiana & Tree & -- \\
\hline Swamp blackgum & Nyssa sylvatica var. biflora & Tree & -- \\
\hline Blackgum & Nyssa sylvatica var. sylvatica & Tree & -- \\
\hline Spruce pine & Pinus glabra & Tree & -- \\
\hline Longleaf pine & Pinus palustris & Tree & -- \\
\hline Loblolly pine & Pinus taeda & Tree & -- \\
\hline Laurel oak & Quercus hemispherica & Tree & -- \\
\hline Swamp laurel oak & Quercus laurifolia & Tree & -- \\
\hline Water oak & Quercus nigra & Tree & -- \\
\hline Virginia live oak & Quercus virginiana & Tree & -- \\
\hline Slimleaf pawpaw & Asimina angustifolia & Shrub & Y \\
\hline Beautybush & Callicarpa americana & Shrub & Y \\
\hline sandweed & Hypericum fasciculatum & Shrub & $\mathrm{Y}$ \\
\hline Gopher apple & Licania michauxii & Shrub & $Y$ \\
\hline Dwarf live oak & Quercus minima & Shrub & Y \\
\hline Running oak & Quercus pumila & Shrub & $Y$ \\
\hline Winged sumac & Rhus copallina & Shrub & $\mathrm{Y}$ \\
\hline Saw palmetto & Serenoa repens & Shrub & $\mathrm{Y}$ \\
\hline Highbush blueberry & Vaccinium corymbosum & Shrub & $Y$ \\
\hline Mayberry & Vaccinium elliottii & Shrub & $Y$ \\
\hline Shiny blueberry & Vaccinium myrsinites & Shrub & $\mathrm{Y}$ \\
\hline
\end{tabular}




\begin{tabular}{|c|c|c|c|}
\hline Common name & Scientific name & Growth form & $\begin{array}{c}\text { Potential suitability for new } \\
\text { development }\end{array}$ \\
\hline Deerberry & Vaccinium stamineum & Shrub & $\mathrm{Y}$ \\
\hline Rabbit-eye blueberry & Vaccinium virgatum & Shrub & Y \\
\hline Texas vervain & Verbena halei & Shrub & $Y$ \\
\hline Groundsel tree & Baccharis glomeruliflora & Shrub & -- \\
\hline Round-pod St. John's-wort & Hypericum cistifolium & Shrub & -- \\
\hline Heart-leaved St. Peter's-wort & Hypericum tetrapetalum & Shrub & -- \\
\hline Myrtle dahoon & Ilex cassine var. myrtifolia & Shrub & -- \\
\hline Sweet gallberry & Ilex coriacea & Shrub & -- \\
\hline Gallberry & Ilex glabra & Shrub & -- \\
\hline Virginia willow & Itea virginica & Shrub & -- \\
\hline Fetterbush & Lyonia lucida & Shrub & -- \\
\hline Wax myrtle & Myrica cerifera & Shrub & -- \\
\hline Swamp azalea & Rhododendron viscosum & Shrub & -- \\
\hline St. Andrew's-cross & Hypericum hypericoides & Herbaceous flower/subshrub & -- \\
\hline Myrtle-leaf St. John's-wort & Hypericum myrtifolium & Herbaceous flower /subshrub & -- \\
\hline Elliot's aster & Symphyotrichum elliottii & Herbaceous flower /sub-shrub & -- \\
\hline Blueheart & Buchnera Americana & Herbaceous flower & $Y$ \\
\hline Leavenworth's tickseed & Coreopsis leavenworthii & Herbaceous flower & $\mathrm{Y}$ \\
\hline Swamp milkweed & Asclepias perennis & Herbaceous flower & -- \\
\hline Coastalplain St. John's-wort & Hypericum brachyphyllum & Herbaceous flower & -- \\
\hline pineweeds & Hypericum gentianoides & Herbaceous flower & -- \\
\hline Cardinalflower & Lobelia cardinalis & Herbaceous flower & -- \\
\hline Frog-fruit & Phyla nodiflora & Herbaceous flower & -- \\
\hline Lizard's tail & Saururus cernuus & Herbaceous flower & -- \\
\hline Canada goldenrod & Solidago altissima & Herbaceous flower & -- \\
\hline Leavenworth's goldenrod & Solidago leavenwothii & Herbaceous flower & -- \\
\hline Sweet goldenrod & Solidago odora var. odora & Herbaceous flower & -- \\
\hline Fine leaf blazing-star & Liatris tenuifolia & Herbaceous flower & Y \\
\hline Bromelike sedge & Carex bromoides & Graminoid (grass-like plant) & -- \\
\hline Clustered sedge & Carex glaucescens & Graminoid (grass-like plant) & -- \\
\hline Greater bladder sedge & Carex intumescens & Graminoid (grass-like plant) & -- \\
\hline Walter's sedge & Carex striata & Graminoid (grass-like plant) & -- \\
\hline Elliot lovegrass & Eragrostis elliottii & Graminoid (grass-like plant) & -- \\
\hline Florida paspalum & Paspalum floridanum & Graminoid (grass-like plant) & -- \\
\hline Eastern gamagrass & Tripsacum dactyloides & Graminoid (grass-like plant) & -- \\
\hline Cinnamon fern & Osmunda cinnamomea & Fern & -- \\
\hline Bracken & Pteridium aquilinum & Fern & -- \\
\hline Southern shield fern & Thelypteris kunthii & Fern & -- \\
\hline
\end{tabular}

